Систематика, филогения и
вопросы эволющии водорослей

ISSN 0868-8540. Algologia. 2015, 25(2): 198-210

UDK 582.26: 556.55

L.N. BUKHTIYAROVA

Institute for Evolutionary Ecology, NAS of Ukraine, Akad. Lebedev St., 37, Kiev 03143, Ukraine

\title{
CLASSIFICATION OF UNISERIAL STRIAE IN BACILLARIOPHYTA WITH BIPOLAR FRUSTULE
}

The striae are the main structural-functional units in the diatom frustule, however, their morphology is still insufficiently studied and poorly used in Bacillariophyta taxonomy. New criteria for the stria architecture analysis rely on the data from electron microscopy investigations. For the first time hierarchical classification of the striae diversity in the diatom bipolar frustules was proposed. It reflects species ontogeny and the influence of ecology in evolution of different striae. Striae types were determined according to areolae types and originally defined stria parameters. Morphology of areolae determines macroareolar, postmacroareolar, combined and polyareolar striae types which are considered as the consistent stages in evolution of the striae in bipolar frustule. Our concept on the derivation of prevail in Bacillariophyta polyareolar stria from the macroareolar stria through the intermediate stria types is supported by similar morphological stages and their consistency recorded in frustule ontogeny of the species from different systematic groups of Bacillariophyta with bipolar symmetry. Basal and interbasal stria types were defined in accordance with the stria location within a basal siliceous layer. Conical type of areola and polyareolar stria with conical areolae are described. Their distinction from poroid areolae and polyareolar stria with poroid areolae is discussed. Proportional, compact and distant kinds of striae are defined on the ratio between stria and interstria areas and their meaning in species biology and ecology is indicated. All the definitions of the frustule structural units are based on the concept of functional morphology of the diatom frustule suggested by the author.

Key words: functional morphology, $d b$-element, $d f$-morph, terminology, macroareola, postmacroareola, poroid areola, conical areola; stria: basal, interbasal, macroareolar, postmacroareolar, combined, polyareolar, proportional, distant, compact, transformed; frustule: monosymmetrical, bisymmetrical, three-symmetrical.

\section{Introduction}

For a long time the number of the rows with areolae within a stria was the only character of stria morphology applied in description of the diatom taxa. Diatoms studied with electron microscopy displayed large diversity in stria morphology. However, these data are not yet reflected in modern systematic of Bacillariophyta. At present only alveolate or chambered stria type is distinguished in the diatom frustule. An alveola was defined as "an elongated

(C) L.N. Bukhtiyarova, 2015 
chamber or one of a series of elongated chambers running from the axial or central part of the valve to the margin, opening to the inside of the frustule by a large opening and with an areolate outer layer", for example, in Pinnularia viridis (Nitzsch) Ehrenb. and species of Cyclotella Kütz. (Ross et al., 1979: p. 527). Later the term alveolate stria was suggested (Cox, Ross, 1981). Different kinds of "chambering" in raphid genera Progonoia H.-J. Schrad., Scoliotropis Cleve, some species of Gomphonema Ehrenb. and Gomphoneis Cleve, araphid Gephyria media Arn. were discussed from ontogenetic point of view (Cox, 2012).

The aim of present study is to designate key morphological parameters of stria that allow to distinguish them precisely and to propose the definitions for the striae diversity found in different Bacillariophyta taxa with bipolar frustule.

\section{Materials and methods}

The materials for our study were collected over a long period in different hydrotopes in the Ukraine. The micrographs of Psammothidium vernadskyi Bukht. et Stanislav. were taken from the sample collected by I.L. Kusin from little lake (Blue Lake N 29), Russia, East Siberia, $70 \mathrm{~km}$ south-east of city Hanty-Mansiysk. Samples were treated on standard methods (Krammer, Lange-Bertalot, 1986). Equipment includes scanning electron microscope JEOL 6060LA, Japan; transmission electron microscope JEOL JEM 1230.

\section{Results and discussion}

\section{General definitions}

Frustule symmetry has significant importance in Bacillariophyta taxonomy. Traditionally diatom frustule symmetry is defined on the quantity of symmetric sections and axes that can cross it (Diatomovy ..., 1949). Bilateral bipolar frustule may possess following mutually perpendicular planes of symmetry: valvar (стулкова площина in Ukr., створковая плоскость in Rus.), longitudinal (подовжня площина in Ukr., продольная плоскость in Rus.) and transverse ones (поперечна площина in Ukr., поперечная плоскость in Rus.). Different bilateral bipolar frustules can be crossed on one-three pairs of equal (symmetrical) parts. Thus, the term bilateral is insufficient for the precise description of the diatom frustule symmetry. Therefore we have introduced following new terms.

Monosymmetrical frustule (Eng., моносиметричний панцир in Ukr., моносимметричный панцирь in Rus.) - frustule that can be crossed with one plane of symmetry. This type of frustule symmetry characterizes of Rhoicosphaenia Grunow (symmetrical on longitudinal plane of symmetry).

Bisymmetrical frustule (Eng., двосиметричний панцир in Ukr., двусимметричный панцирь in Rus.) - frustule that can be crossed with two planes of symmetry. An example of such frustule symmetry is Eunotia (symmetrical on valvar and transversal planes of symmetry).

Three-symmetrical frustule (Eng., трисиметричний панцир in Ukr., трисимметричный панцирь in Rus.) - frustule that can be crossed with three 
planes of symmetry. An example of this frustule symmetry is Navicula Bory (symmetrical on valvar, longitudinal and transversal planes of symmetry).

For the first time proposed terminology was applied in the descriptions of the new taxa from Lake Baikal (Bukhtiyarova and Pomazkina, 2013).

For the species with bilateral bipolar symmetry a stria were redefined as "... depressions sunk into surface of the valve" (Cox and Ross, 1981). In the terms of functional morphology stria of the diatom frustule (штрих панциря діатомових водоростей in Ukr., штрих панциря диатомовых водорослей in Rus.) is a universal repeated micro- $d f$-morph of third (second) order, the area with areolae restricted by neighboring virgae. Stria functions provide interaction of protoplast with environment through the hierarchical system: $d f$-converter-areola-stria. Different processes, stria functions, take place in stria area: selective concentration of the matters on their surface, matters absorption/excretion, intensification of physiological processes connected with cell membrane, focusing and filtering of light and others. Evolution of a stria reflects the development of its functions depending on particular environmental conditions (Bukhtiyarova, 2009).

Basic element of the diatom frustule (= db-element, Eng., базисний елемент панциря діатомових водоростей, $=$ db-елемент in Ukr., базисный элемент панциря диатомовых водорослей, $=d b$-элемент in Rus.) morphologically detached, homogeneous frustule component, that possesses special physical-chemical features and provides a primary base for the diatom frustule hierarchical construction. They belong to $d b$-elements of a diatom frustule as different apertures and cavities in its thickness, regularly repeated and unique silica components.

Morph of the diatom frustule $(=d f$-morph, Eng.; морфа панциря діатомових водоростей, $d f$-морфа in Ukr.; морфа панциря диатомовых водорослей, $d f$-морфа in Rus.) - compound structural unit of the diatom frustule that consists the $d b$-elements or structural units of lower orders, or both of them, realizes particular functions for the diatom organism and has own evolution (Bukhtiyarova, 2009).

The term virga was proposed as the "... bars between the striae" to distinguish interstrial bars into interior of the frustule in pinnate diatoms of Naviculaceae or Eunotiaceae from the true costae in Diatomaceae or some Nitzschiaceae (Cox and Ross, 1981). In the same paper the term vimin was suggested for the "crossbars" between virgae. Lately virga was defined "... ontogenetically as the transverse bars that develop from the sternum" (Cox, 2012). Our definitions are based on functional morphology.

Virga (Lat., вірга in Ukr., вирга in Rus.) - universal repeated siliceous micro- $d b$-element in form of long siliceous bar that restricts stria area and protects it from mechanical stress (Bukhtiyarova 2009: figs 1-6: v).

Vimin (Lat., ваймін in Ukr., ваймин in Rus.) - universal repeated siliceous nano- $d b$-element in form of the plates or short bars between areolae. The type and arrangement of the vimines within striae area determine the pattern of areolae arrangement in a stria (Bukhtiyarova, 2009: figs 2-5: $n$ ). 
Areola (Lat., ареола in Ukr., ареола in Rus.) - universal repeated nano(micro-) $d f$-morph of third/second order that includes a hollow in the frustule siliceous layer, one or two $d f$-converters and organized in a stria. Functions of areola coincide partially with the stria functions. It is obvious that $d f$-converter morphology defines the most important characteristics of areola. However, other parameters, like areola hollow length and shape into the frustule thickness, its inner surface etc, determine areola functions as well (Bukhtiyarova, 2009).

Converter of the diatom frustule (=df-converter, Eng., $d f$-перетворювач in Ukr., $d f$-преобразователь in Rus.) syn.: velum, occlusion - universal, repeated nano- (micro-) $d f$-morph of first order that consists fine aperture (-s) and siliceous $d b$-element (-s), locates within areola and carries out direct interaction between protoplast and environment: matters absorption/ excretions, light energy focusing and filtering; biological, chemical protecting and others. $D f$-converter transforms the effects of environmental factors in suitable for diatom organism manner and values however these basic functions are not reflected in any of earlier suggested terms which only indicate the fact of areola closing (Bukhtiyarova, 2009).

\section{Types of striae}

In our opinion, the type of stria is determined by the type of areolae, their arrangement within stria area and other stria parameters. Morphology of areolae assigns following stria types.

Macroareolar stria (Lat., макроареолярний штрих in Ukr., макроареолярный штрих in Rus.) (Figs 3-5) - type of stria that consists of macroareola.

According to definition, macroareola (макроареола in Ukr., макроареола in Rus.) is a type of areola in which the foramen occupies the whole stria area and closed by flat sieve $d f$-converter (Bukhtiyarova, 2006: figs 3, 4). Thus, macroareolar stria is equal morphologically to one macroareola.

Postmacroareolar stria (Lat., постмакроареолярний штрих in Ukr., постмакроареолярный штрих in Rus.) Figs 6-7a - type of stria that consists of postmacroareolae. Several postmacroareolae may occupy a whole stria area.

Postmacroareola (Lat., постмакроареола in Ukr., постмакроареола in Rus.) Figs 7a, 17, $d f-c-$ areola with large foramen of irregular size and shape even within one stria, occupying large part of stria area and closed by sieve $d f$ converter (Bukhtiyarova, 2006: figs 1, 2).

Morphology of postmacroareolar stria clearly proves that in evolution process it apparently was an intermediate stria type between macroareolar and polyareolar stria, one of the prevalent stria types of different systematic groups Bacillariphyta. In particularly, both in macroareolar stria and postmacroareolar one the previmins often are present.

Previmin (Lat., предваймін in Ukr., предваймин in Rus.) fig. 7, arrows repeated siliceous nano- $d b$-element in form of incomplete transverse plates of irregular form and location partially crossed macroareola or postmacroareola 
foramen. Their actual function is in reinforcing of striae area with large $d f$ convertes. The previmines evolutionally precede to the vimines.

Observations of stria development during valve ontogeny in the diatoms with bipolar symmetry have showed that the vimins start to form when virgae shaping has been completed and that became the base for a concept of stria as a single areola covered by velum with transverse ribs (Schmid and Schulz, 1979). Such a pattern of valve morphogenesis was confirmed in different systematic groups of Bacillariophyta with bipolar symmetry (Mayama and Kobayasi, 1989; Cox, 2012). The result of comparative morphological study of Karayevia species coincides with the ontogeny data therefore hypothesis about derivation of stria with poroid areolae from macroareolar striae via postmacroareolar striae was suggested (Bukhtiyarova, 2006). Recent data also pointed out the appearance of the vimins on the late stages of virgae formation (Cox, 2012: figs 5b, $f, h$ ) which morphology is similar to the previmins on this ontogeny stage but differ from them in the regular location within stria area. Thus, the presence of the previmins in macroareolae and postmacroareolae indicates on similarity of evolutional processes of those areola types and maintains our concept of polyareolar stria derivation.

Polyareolar stria (Lat., поліареолярний штрих in Ukr., полиареолярный umpux in Rus.) - type of stria that consists the groups of the areolae with regular morphology and certain pattern of allocation within stria area (Figs 1, $10-12)$.

Stria with poroid areolae (= poroid stria Lat.-Eng.; штрих із пороїдними ареолами, пороїдний штрих in Ukr., штрих с пороидными ареолами, = пороидный штрих in Rus.) - polyareolar type of stria that consists poroid areolae in a row with uniform vimins (Figs 1, 10-12).

Poroid areola (Lat., пороїдна ареола in Ukr., пороидная ареола in Rus.) type of areola with uniform tube-like hollow into the frustule silica, sieve $d f$ converter on outer and flap-like $d f$-converter on inner valve surface (Fig. 1).

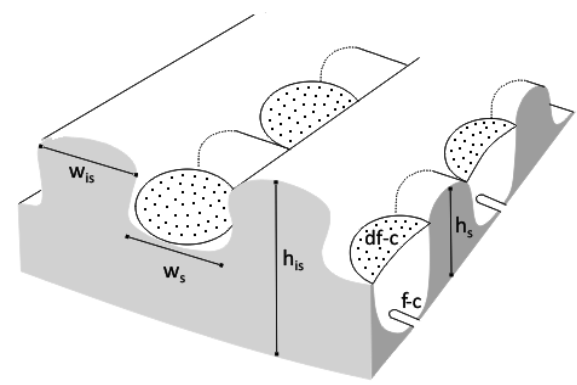

1

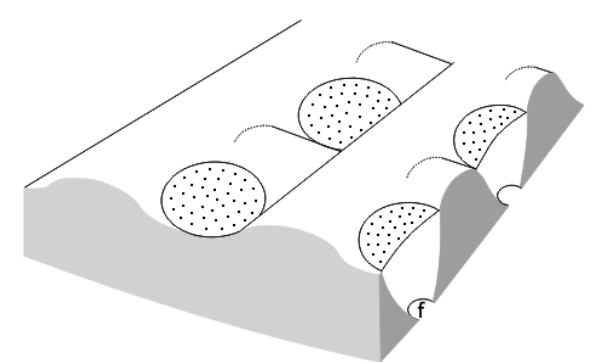

2

Figs 1, 2. Scheme section across the striae and areolae in the diatom frustule with bipolar symmetry. 1 - Interbasal stria with poroid areolae; 2 - basal stria with conical areolae. $d f-c-d f$-converter, $f-$ outer areola foramen, $f$-c - flap-like $d f$-converter, $h_{\text {is }}-$ height of interstria area, $h_{\mathrm{s}}-$ height of stria area, $w_{\text {is }}-$ width of interstria area, $w_{\mathrm{s}}-$ width of stria area 
Poroid areola was initially described as an areola which hollow has not noticeable widening into the valve thickness (Nikolaev, 1984).

Stria with conical areolae (= conic-areolar stria Lat.-Eng.; штрих iз конічними ареолами, конічно-ареолярний штрих in Ukr., штрих $c$ коническими ареолами, конически-ареолярный штрих in Rus.) - polyareolar type of stria that consists conical areolae in a row with uniform vimins (Figs 13-15).

Conical areola (Lat., конічна ареола in Ukr., коническая ареола in Rus.) type of areola with truncated conical hollow into the valve thickness, usually, small outer foramen and considerably larger inner foramen with sieve $d f$ converter (Figs 2, 13-15). Normally $d f$-converters are set on the props or on the tapes.

The key morphological differences of conical areola from poroid one are: 1) conical hollow into frustule silica instead tube-like one, 2) single $d f$-converter of sieve type on inner valve surface while poroid areola has both inner sieve $d f$-converter and outer flap-like $d f$-converter of various morphology (= vola accoding to Ross and Sims, 1972); Mann, 1981; = foricula accoding to Cox, 2004). It was earlier underlined that " ... slit-like external areola openings within the Naviculales (Table 2) are not described as volate" Cox (2004). However, in our opinion the areolae in both the genera Navicula Bory and Cymbella C. Agardh possess outer flap-like $d f$-converter with slit-like opening. An example of conical areolae in proportional striae can be found on illustrations of Placoneis sovereignae (Hust.) Torgan et Donadel (Torgan et al., 2010: figs 12, 14).

Areola prop (Eng., стовпчик ареоли in Ukr., столбик ареолы in Rus.) repeated nano- $d b$-element in form of siliceous strut that serves for $d f$-converter fixing (Figs 12, 20-22, arrows).

The term prop or supporting prop was suggested earlier without any definition (Cox, 2004).

Areola tape (Eng., тасьма ареоли in Ukr., тесьма ареолы in Rus.) repeated nano- $d b$-element in form of thin siliceous strip that serves for $d f$-converter fixing (Figs 19-22, arrows).

It is unknown yet exactly whether in the same valve both props and tapes can be present (Figs 19-22) or in this case the false props are appeared as a result of tape destroying. We suppose as well that tapes can be formed between props and mask the later ones.

Combined stria (Eng., комбінований штрих in Ukr., комбинированный штрих in Rus.) - polyareolar kind of stria that consists regular row (-s) of areolae with uniform vimins and postmacroareolae.

Combined striae are relatively rare in the diatoms with bipolar frustule but occur in different genera and systematic orders that indirectly prove their intermediate position in stria evolution. Usually postmacroareolae in combined striae are allocated at valve margin or/and at valve mantle: Psammothidium frigidum (Hust.) Bukht. et Round (Bukhtiyarova and Round, 1996: fig. 58), Fistulifera saprophyla (Lange-Bert. et Bonik) Lange-Bert. 
(Lange-Bertalot, 2001: Pl. 111, fig. 4), Fistulifera pelliculosa (Bréb.) LangeBert. (Lange-Bertalot, 2001: Pl. 112, fig. 1).

Thus, combined striae can be considered as second intermediate stage in derivation of polyareolar stria from macroareolar one through postmacroareolar and combined striae.

\section{Parameters of stria in the diatom frustule}

Besides of morphologically different areolae following parameters are characterized the striae of the diatom frustule.

Stria area $\left(\mathbf{S}_{\mathrm{st}}\right)$ (Eng., площа штриха in Ukr., площадь штриха in Rus.) the diatom frustule area restricted by neighboring virgae that a set of areolae occupies.

Interstria area $\left(\mathbf{S}_{\mathrm{ist}}\right)$ (Eng., міжштрихова площа in $\mathrm{Ukr.,} \mathrm{межштриховая}$ площадь in Rus.) - the diatom frustule area that virga occupies.

The term interstria in fact was not accepted in today diatom morphology and recently has been distinguished from the virgae: “... interstriae recognized under LM may not correspond to virgae sensu Cox and Ross (1981). Virgae are defined ontogenetically as the transverse bars that develop from the sternum in pennate diatoms" (Cox, 2012: p. 18). However, as it was shown above, the ontogeny pattern of the striae in bipolar frustule is similar in taxonomically different diatoms both in general stages and their sequence. Therefore the term virga has universal and more wide meaning than in it's original definition. Moreover, virgae have subordinate, assistant functions regarding to the striae - the main functional unit in the diatom frustule (Bukhtiyarova, 2009). So, according to our concept of stria architecture there is no need to discuss virgae as the costae or not costae etc., since all the definitions focus attention on the stria morphology which includes virgae morphology as a character of particular stria type. Besides that the proposed here term interstria area is not a morphological structure but one of a frustule parameter.

Interstria height $\left(\mathrm{H}_{\mathrm{ist}}\right)$ (Eng., висота кремнезему у міжсштриховій області in Ukr., высота кремнезема в межштриховой области in Rus.) thickness of the basal siliceous layer in virga area (Figs 1, 2)

Depending on stria parameters following stria types were observed in the diatom frustules with bipolar symmetry.

Basal stria (Eng., базальний штрих in Ukr., базальный штрих in Rus.) type of stria that areolae and all additional $d b$-elements accompanied them are sited within interstria height (Figs 2, 10-15). This stria type species of Achnanthidium Kütz., Placoneis Mereschk. have.

Interbasal stria (Eng., міжбазальний штрих in Ukr., межббазальный uтрих in Rus.) - type of stria that areolae and additional $d b$-elements accompanied them are sited within a part of interstria height (Figs 1, 16-18). This stria type the species of Navicula s. str. and Cymbella s. str. have. 
Kinds of striae

Proportional stria (Eng., пропорційний in Ukr., пропорциональный uтрих in Rus.) - kind of stria that stria area is approximately equal to interstria area $\left(\mathbf{S}_{\mathrm{ist}}: \mathbf{S}_{\mathrm{st}}=\mathbf{1}\right)$ (Figs $\left.5,7,18\right)$.

Packed stria (Eng., ущільнений in Ukr., уплотненный штрих in Rus.) kind of stria that stria area is two or more times as much than interstria area $\left(\mathbf{S}_{\text {ist }}: \mathbf{S}_{\text {st }} \leq \mathbf{0 . 5}\right)($ Figs 3, 16).

Distant stria (Eng., розріджений штрих in Ukr., разреженный штрих in Rus.) - kind of stria that stria area is two or more times as less than interstria area $\left(\mathbf{S}_{\text {ist }}: \mathbf{S}_{\text {st }} \geq 2\right)($ Figs 4, 6, 8, 9, 10-13, 17).

Because the density of areolae on the valve with proportional and packed striae are much higher than in the ones with distant striae it is obviously that in species with first two kinds of striae the exchange of matters with environment is much intensive than in species with distant striae. So, observed gradation of striae morphology reflects biological characteristics of species and can be useful in ecological investigations.

\section{Variety of striae}

Transformed stria (Eng., трансформований штрих in Ukr., трансформированный, изменяющийся штрих in Rus.) - stria that consists the groups of areolae with the foramens or the flap openings of the $d f$-converters in different size and transitional shape. Poroid striae with outer slit-like flap $d f$ converters often gradually changes the shape of the flap openings from slit-like to shorter slits and even roundish ones especially at central valve part as in many Navicula and Cymbella species (Fig. 17). In species with bimultyseriate striae the number of the rows with areolae may change gradually, making a transformed striae like in Planothidium Round et Bukht., Gomphoneis Cleve. Variety of stria usually has species rank of taxonomy if other species characters completely correspond to a genus diagnosis. In case when the stria variety make up a set with other characters that distinguishes a group of the species, it may correspond to genus rank of taxonomy.

\section{Conclusions}

Morphological criteria and essential principles of striae architecture in the diatom frustule are grounded on the data of electron microscopy and functional morphology. The proposed classification of newly described striae includes co-subordinate units - types, kinds and variety in diversity of the striae, which were found in the diatom species with bipolar symmetry. The concept of an evolutional derivation of polyareolar striae from macroareolar striae through the intermediate postmacroareolar and combined ones was confirmed both with comparative morphological and ontogeny studies. The progress in development of terminology will contribute to the exact and short taxa diagnosis that is an actual task in today Bacillariophyta taxonomy.

The author greatly thanks to Dr. Nikolay Scherbatyuk for assistence on taking of TEM micrographs, Dr. Sci. professor Michael Guiry, Ryan Institute, Ireland, for English correction. 


\section{REFERENCES}

Bukhtiyarova L.N. and Pomazkina G.V., Bacillariophyta of Lake Baikal, Vol. 1, Lviv, 2013.

Bukhtiyarova L.N. and Round F.E., Diatom Res., 11(1):1-30, 1996.

Bukhtiyarova L.N., Nova Hedw., 130:85-96, 2006.

Bukhtiyarova L.N., Algologia, 19(3):321-331, 2009.

Cox E.J. and Ross R., Proceedings of the 6-th Diatom Symposium, Koeltz Sci. Books, Koenigstein, Pp. 267-278, 1981.

Cox E.J., Diatom 20:33-46, 2004.

Cox E.J., Diatom Res., 2(2):145-157, 1987.

Cox E.J., J. Phycol., 48:1-31, 2012.

Diatomovyj analiz, Eds A.N. Krishtofovicha and A.I. Proshkina-Lavrenko, Gos. Izd-vo Geol. Lit., Leningrad, 1949. [Rus.]

Krammer K. and Lange-Bertalot H., Süsswasserflora von Mitteleuropa, Bd 2-2, VEB Gustav Fischer Verlag, Jena, 1986.

Lange-Bertalot H., Diatoms of Europe, Vol. 2, Ganter Verlag, Ruggell, 2001.

Mann D.G., Proceedings of the 6th Diatom Symposium, Ed. R. Ross, Koeltz Sci. Books, Koenigstein, Pp. 279-300, 1981.

Mayama S. and Kobayasi H., Diatom Res., 4:111-117, 1989.

Nikolaev V.A., Bot. J., 69(8):1040-1047, 1984. [Rus.]

Ross R. and Sims P.A., Brit. Phycol. J., 7:139-163, 1972.

Ross R., Cox E.J., Karayeva N.I., Mann D.G., Paddock T.B.B., Simonsen R., and Sims P.A., Nova Hedw., 64:513-533, 1979.

Round F.E., Crawford R.M., and Mann D.G., The Diatoms. Biology and Morphology of the Genera, Cambridge Univ. Press, Cambridge, 1990.

Schmid A.M. and Schulz D., Protoplasma, 100:267-288, 1979.

Torgan L.C., Donadel L., and Gonzalves da Silva J., Iheringia, Ser. Bot., 65(1):107-114, 2010.

Received 08.04.2014

Submitted by S.P. Wasser

ISSN 0868-8540. Algologia. 2015, 25(2): 198-210

http://dx.doi.org/10.15407/alg25.02.198

Л.Н. Бухтиярова

Институт эволюционной экологии НАН Украины,

ул. Акад. Лебедева, 37, Киев 03143, Украина

КЛАССИФИКАЦИЯ ОДНОРЯДНЫХ ШТРИХОВ У BACILLARIOPHYTA

С БИПОЛЯРНЫМ ПАНЦИРЕМ

Штрихи являются основными структурно-функциональными единицами панциря Bacillariophyta, однако их морфология остается не достаточно изученной и ограничено используется в таксономии Bacillariophyta. Новые критерии для анализа архитектуры штриха базируются на данных электронной микроскопии. Впервые предложена иерархическая классификация разнообразия штрихов у Bacillariophyta c биполярной симметрией панциря. Она отражает онтогенез видов и влияние экологии на эволюцию разнообразных штрихов. Типы штрихов панциря диатомовых водорослей различаются по типам ареол и предложенным автором параметрам 
штриха. Морфология ареол определяет макроареолярный, постмакроареолярный, комбинированный и полиареолярный типы штрихов, которые рассматриваются как последовательные стадии эволюции штрихов Bacillariophyta. Концепция возникновения превалирующего у Bacillariophyta полиареолярного штриха из макроареолярного через промежуточные типы штрихов подтверждается подобными морфологическими стадиями и их последовательностью в онтогенезе штриха у видов Bacillariophyta с биполярной симметрией, относящихся к различным таксономическим группам. Базальный и межбазальный типы штрихов определены по их расположению в пределах кремниевого слоя панциря. Описаны конический тип ареол и полиареолярный штрих с коническими ареолами. Обсуждается их отличие от пороидных ареол и пороидного штриха. Пропорциональные, уплотненные и разрежсенные виды штрихов определены по соотношению между площадью штриха и межштриховой площадью, показано их значение в биологии и экологии видов. Разновидность штриха - трансформированный - определена по изменению фораменов в группах ареол в пределах одного штриха. Все определения структурных единиц панциря сформулированы на основании концепции функциональной морфологии панциря Bacillariophyta, предложенной автором ранее.

Кл юч е в ы е слов а : функциональная морфология, $\quad d b$-элемент, $d f$-морфа, терминология, макроареола, постмакроареола, пороидная ареола, коническая ареола; штрих: базальный, межбазальный, макроареолярный, постмакроареолярный, комбинированный, полиареолярный, пропорциональный, разреженный, уплотненный, трансформированный; панцирь: моносимметричный, бисимметричный, трисимметричный. 


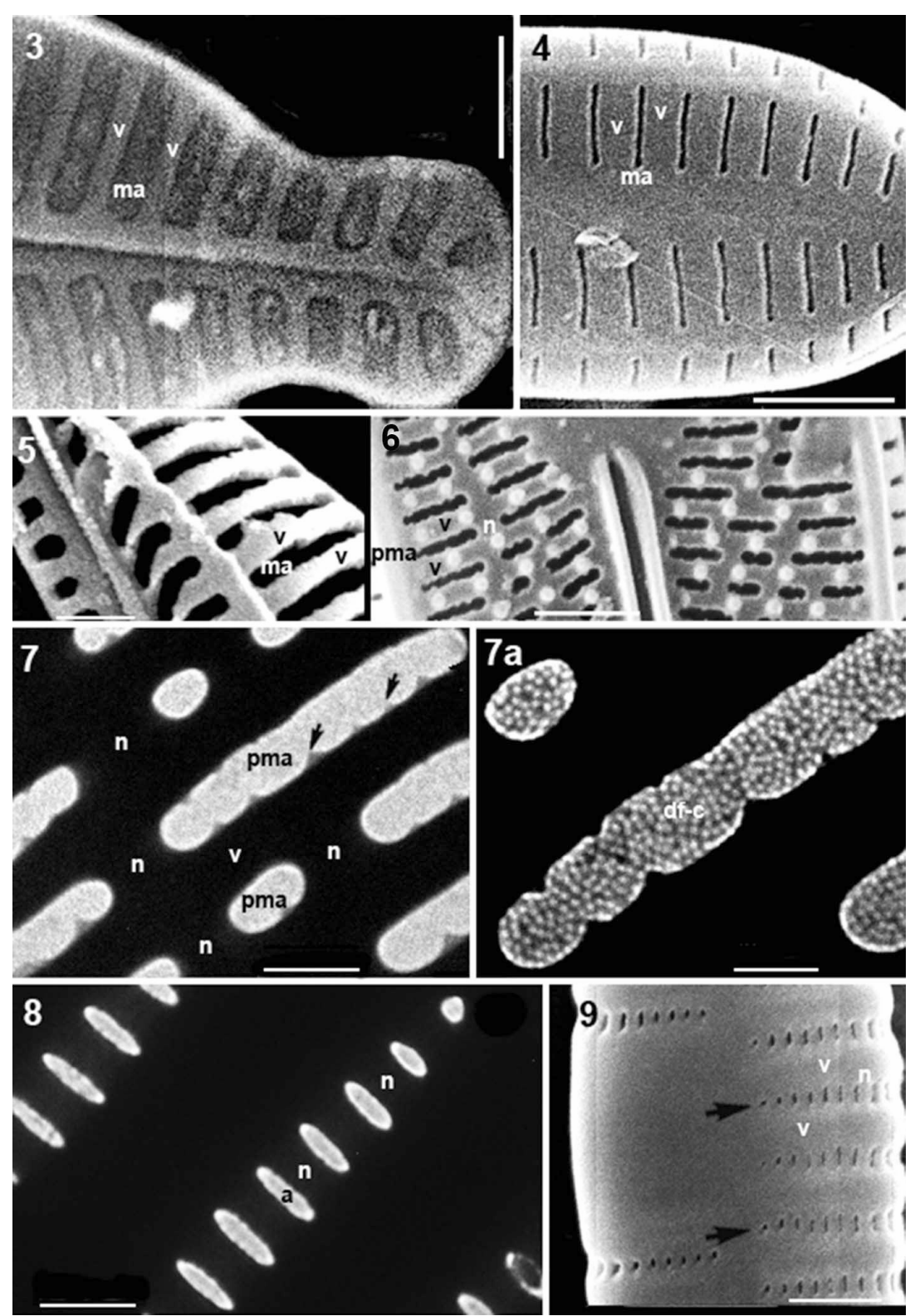

Figs 3-9. Types of striae in the diarom frustule with bipolar symmetry. 3 - macroareolar striae, Karayevia sp., fragment of raphe valve, outer surface; 4, 5 - macroareolar striae, interrupted at valve mantle junction: 4 - distant striae, Karayevia sp. 1, fragment of rapheless valve, outer surface, 5 - proportional striae, Amphora sp., outer surface, $d f$-convertors are destroyed; 6, 7, 7a - postmacroareolar striae: 6 - distant striae, Brachysira sp., 7, 7a - proportional striae with sieve $d f$-convertors, Brachysira sp. 1; previmins, arrows; 8, 9 - basal, distant, transformed striae with poroid areolae: 8 - fragment of valve Fragilaria sp., 9 - transformed striae, arrows, central part of valve Fragilaria sp. 1, outer surface. $a-$ areola, $d f-c-$ sieve $d f$-converter, ma macroareola, pma - postmacroareola, $n-$ vimin, $v$ - virga. Figs 3-6, 9 - SEM; 7, 7a, 8 TEM. Scale 3, 5, 6, $9-1 \mu \mathrm{m}, 4-2 \mu \mathrm{m}, 7-250 \mathrm{~nm}, 7 \mathrm{a}-100 \mathrm{~nm}, 8-200 \mathrm{~nm}$ 


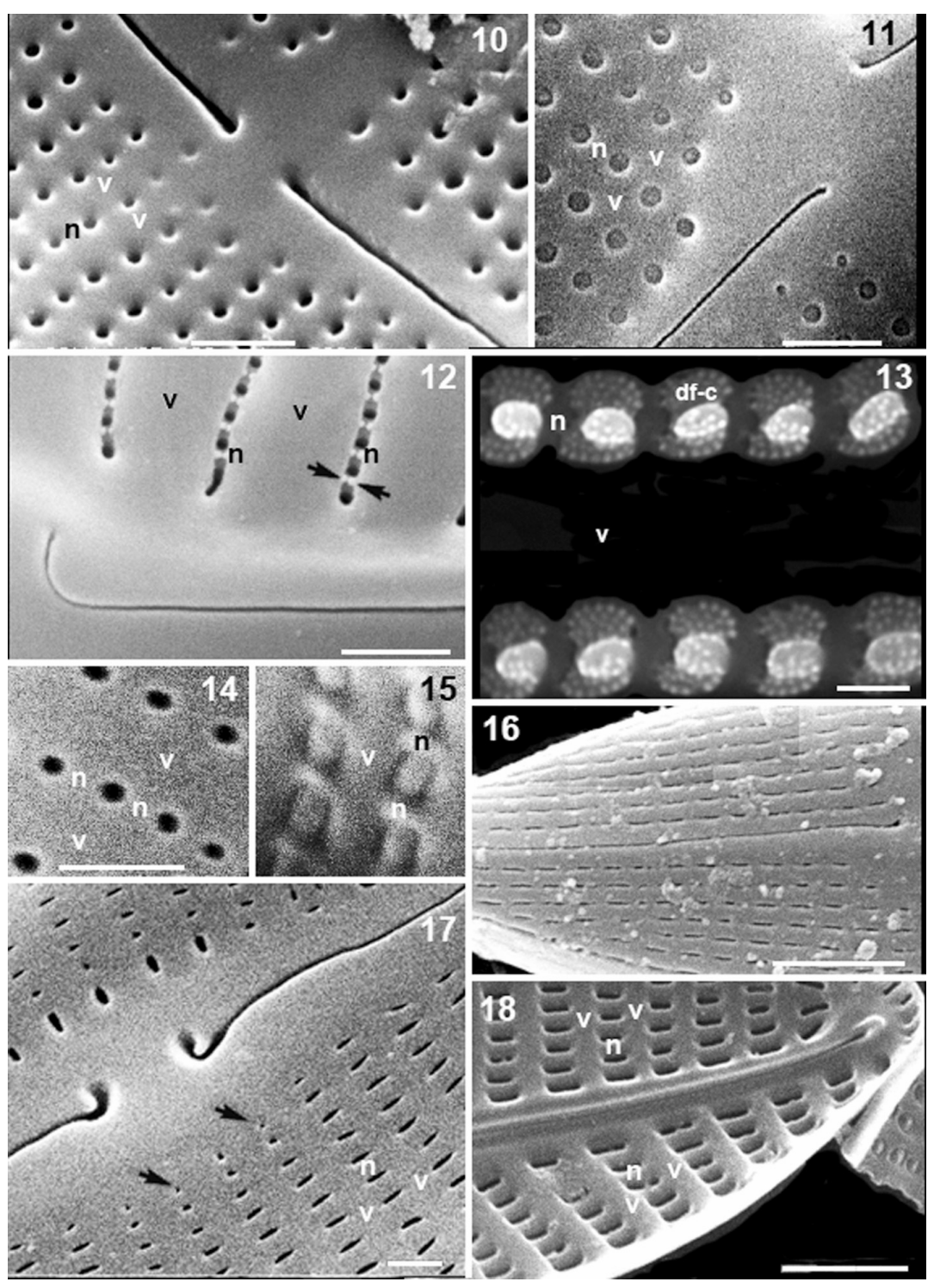

Figs 10-18. Types of striae in the diarom frustule with bipolar symmetry. 10, 11 - polyareolar basal distant striae with poroid areolae, Cocconeis sp., central part of raphe valve from outer and inner surface; 12-15 - polyareolar basal striae with conical areolae: 12 - distant striae, Encyonema sp., central part of valve from inner surface; areola props, arrows, 13 - distant striae, Psammothidium sp., 14, 15 - proportional sriae, Psammothidium vernadskyi Bukht. et Stanislav., fragments of raphe valve from outer and inner surface; $16-18$ - polyareolar interbasal striae with poroid areolae: 16 - packed striae, Navicula sp., fragment from outer valve surface, 17 transformed striae in central part of Cymbella sp., arrows, outer valve surface, 18 - proportional striae, Navicula sp. 1, fragment of inner valve surface. $d f$-c - sieve $d f$-converter, $n$ - vimin, $v$ - virga. 10-12, 14-18 - SEM; 13 - TEM. Scale 10-12, 16-18 - $1 \mu \mathrm{m}$, $14,15-500 \mathrm{~nm}, 13-100 \mathrm{~nm}$ 


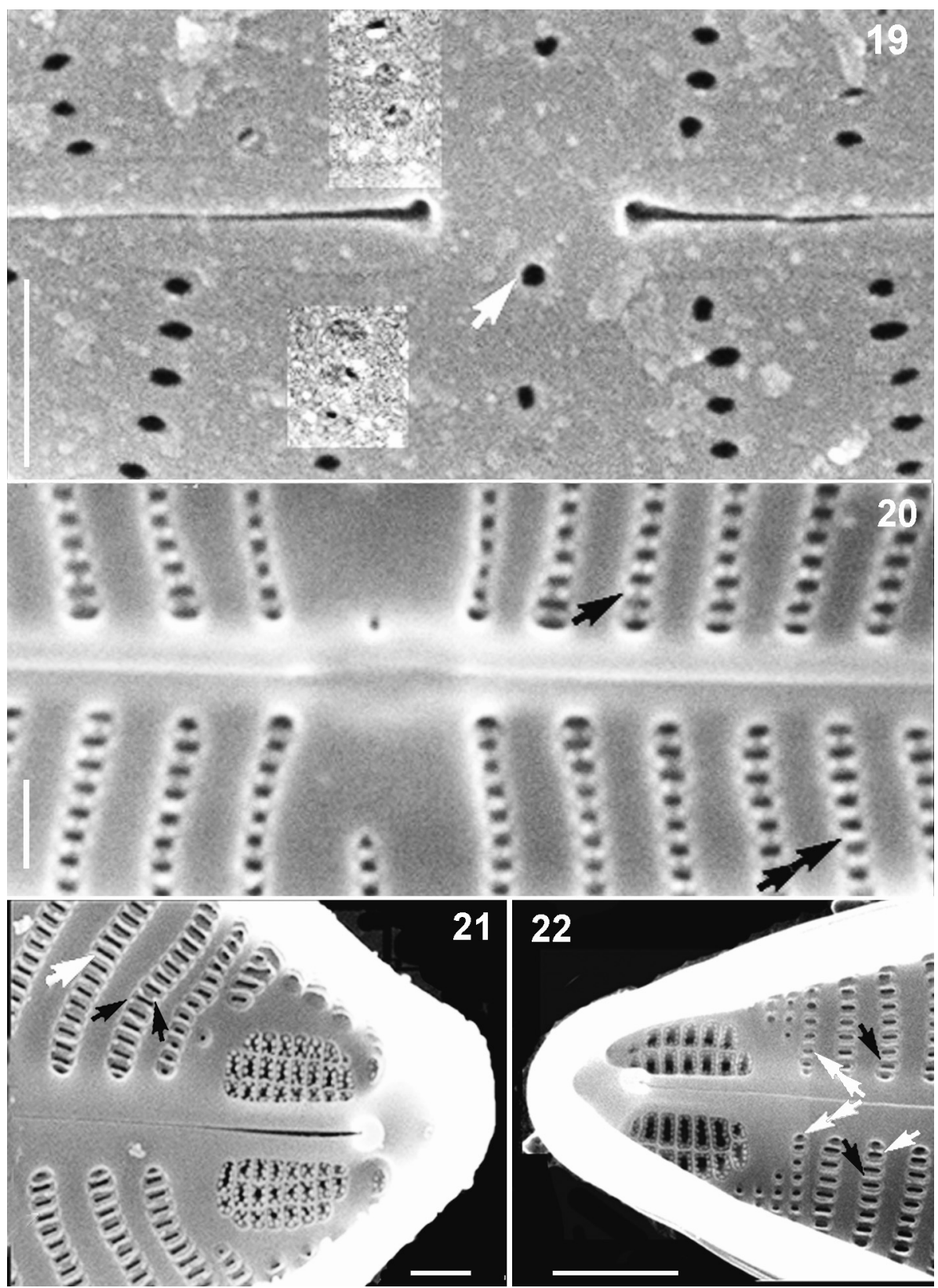

Figs 18-21. Areola $d b$-elements and $d f$-morphs, SEM. $18-$ sieve $d f$-converters in compressed conical areolae, in light rectangles; stigma, arrow; fragment of Placogeia microcephala Pomazk. et Bukht., outer valve surface; 19 - areola props, arrow; areola tape, double arrow; fragment of Placogeia acceptaformis Bukht. et Pomazk., inner valve surface; 20 - areola tape, white arrow; props, black arrows; the pole of Baikalia aleksandrae Pomazk. et Bukht., inner valve surface; 21 - areola tapes, white arrows; prop, black arrow; additional sieve catinus, double arrows; the pole of Nadiya pavla Pomazk. et Bukht., inner valve surface. Scale $19-22-1 \mu \mathrm{m}$ 